\title{
Reflection on Teachers' Personal and Professional Growth Through a Materials Development Seminar
}

\author{
Reflexión sobre el desarrollo profesional y personal de los \\ profesores a través de un seminario en desarrollo de materiales*
}

\author{
Astrid Núñez Pardo \\ astrid.nunez@uexternado.edu.co \\ María Fernanda Téllez Téllez \\ maria.tellez@uexternado.edu.co \\ Universidad Externado de Colombia, Bogotá, Colombia
}

This qualitative action research study explores the role of reflection on teachers' personal and professional growth through the methodology used in the Materials Development Seminar in the Master's Programme in Education with Emphasis on English Didactics at a private university in Colombia. The project was carried out with 31 English as a Foreign Language Teachers. The instruments for data gathering were a survey and a written reflection. The findings suggest that reflection is critical in raising teachers' awareness of personal and professional growth, creating a reflective learning environment and a positive affective state. Additionally, a number of English as a foreign language teachers became text developers with a recognised Colombian publishing house.

Key words: Materials development, multidimensional approach, reflection, teachers' professional and personal development.

Esta investigación acción cualitativa explora el papel de la reflexión en el crecimiento personal y profesional de los profesores, a través de la metodología (enfoque multidimensional) del seminario Desarrollo de Materiales, de la maestría en Educación con énfasis en Didáctica del Inglés en una universi-

* Received: March 16, 2015. Accepted: July 27, 2015.

How to cite this article (APA 6th ed.):

Núñez Pardo, A., \& Téllez Téllez, M. F. (2015). Reflection on teachers' personal and professional growth through a materials development seminar. HOW, 22(2), 54-74.

This article is licensed under a Creative Commons Attribution-NonCommercial-NoDerivatives 4.0 International License. License Deed can be consulted at http://creativecommons.org/licenses/by-nc-nd/4.0/. 
dad privada en Bogotá, Colombia. El estudio se realizó con 31 profesores utilizando dos instrumentos: una encuesta y una reflexión escrita. Los hallazgos sugieren que la reflexión es un aspecto crítico en el crecimiento personal y profesional de los profesores en la concienciación de su desarrollo personal y profesional; en la creación de una atmósfera de reflexión y aprendizaje y un estado de afecto positivo. Adicionalmente, varios profesores son hoy autores de textos de enseñanza de inglés como lengua extranjera en una casa editorial reconocida en Colombia.

Palabras clave: desarrollo de materiales, desarrollo personal y profesional docente, enfoque multidimensional, reflexión.

\section{Introduction}

This qualitative action research study examined how teachers' reflection on the methodology of the materials development (MD) seminar has shaped their personal and professional growth in the Master's Programme in Education with Emphasis on English Didactics (MEED) at a private university. Through our experience with this seminar and reflection on our pedagogical practice, we recognised theoretic and pragmatic problems regarding teachers' praxis in the English as a foreign language (EFL) classroom: disregard of reflection on students' needs, unawareness of learning and teaching approaches and materials, as well as the absence of customized criteria for the selection, development, adaptation, and evaluation of didactic materials.

\section{Theoretical Framework}

\section{Reflection}

Reflection guides teachers to self-dialogue and inquiry that lead the decision-making process within teaching-learning contexts. In this respect, Schön contended that "reflectivity is a dialogue of thinking and doing through which I become more skilful" (as cited in Giovannelli, 2003, p. 293). The author further identified "reflection in action," which entails self-critique when understanding a phenomenon and how we re-describe it through experimentation and "reflection on action" that implies rebuilding and examining actions and events. In light of this, teachers' reflection should start with the EFL classroom assessment, focused on self-assessment of their pedagogical practices, language teaching and materials and their effect on students' learning outcomes, which might enable them to reconstruct and improve a particular teaching and/or learning situation.

Likewise, Rodgers (as cited in Núñez, Ramos, \& Téllez, 2006) argued that reflecting on the teaching context centres teachers on what truly happens in the classroom, not on what they expect to happen. This can be done in a four-stage sequence: "presence in experience" (recognising crucial aspects to alert teachers about why and how to handle a classroom event); 
"describing experience" (objectively addressing classroom observation); "analysis of class performance" (teachers' justification of the issues observed); and "taking intelligent action" (trying out and innovating in the EFL classroom) (p. 112, trans.). Hence, reflection might shape MD and teachers' personal and professional growth. The former benefits from reflection as the core concern of teachers as materials developers to fulfil the learners' needs and interests and the latter capitalises on teachers' awareness of how their reflective practice works and its incidence in their personal and professional development.

Wink (as cited in Núñez et al., 2006) emphasised that the reflection process allows educators to devote time to learn, unlearn, and relearn on their teaching practice. Researchers like Barlett (1990), Pollard and Tann (1993), Viafara (2005), and Wallace (1991) suggested reflective cycles to lead teachers into knowing how they teach, self-assessing their teaching practice and planning to make informed decisions that may refine their teaching. This is related to Rodger's reflective sequence; that is, teachers reflect upon, assess, and act to improve their teaching.

Furthermore, Loughran (2002) claimed that "one element of reflection that is common to many is the notion of a problem. What that problem is, the way it is framed and reframed, is an important aspect of understanding the nature of reflection" (p. 33). Similarly, Núñez et al. (2006) remarked that "reflection should be a constant process among teachers that permits to solve teaching and learning problems" (p. 113, trans.). The notion of a problem fosters reflection since teachers' concerns make them act to alleviate a learning difficulty.

Therefore, what reflection represents in the selection, creation, or evaluation of materials is a learning opportunity for teachers to ponder learners' needs, language learning and teaching theories, principles of second language acquisition (SLA), syllabus design with meaningful and engaging content and activities, application of learning strategies, opportunities for output activities and intended outcome, and creation of effective learning settings. As Núñez and Téllez (2009) affirmed: “The onset of teachers' reflection is the individual assessment of the EFL classroom, which enable[s] them to make decisions when they create or adapt materials that fulfil particular needs and learning setting" (p. 172).

Likewise, what reflection does in teachers' personal and professional development entails the self-recognition and assessment of their teaching aimed at improving their classroom performance through the development of materials that are responsive to their local needs. As Núñez et al. (2006) contended:

Reflecting is a vital activity for professional and personal development since it leads the teacher to a process of self-recognition of his performance and to a self-evaluation that simultaneously allows him to make changes and implement innovations not only to the methodological approach, but 
also to the selection and development of meaningfully contextualized materials. (pp. 114-115, trans.)

Thus, reflecting is a systematic ongoing process among teachers and text developers, which can be done by contextualising materials to gain self-confidence, self-esteem and expertise, and achieve teacher development as well (Tomlinson, 2003).

\section{The Multidimensional Approach}

The multidimensional approach (Tomlinson, 2000) framing the MD seminar consists of giving teachers opportunities, in which a number of learning and communication principles interplay, to have them reflect upon their teaching, the materials and their effect on students' learning results. It favours the affective appeal, meaningful connections between new and old experiences, sensory imaging, inner voice, and pertinent content. In the seminar, affect permeates class activities, scaffolding, and MD modelling. Taniguchi's (2005) words: "affect is produced along with different teachers' orientations towards teaching and the student's reaction to it" (p. 80).

The affect involved in the classroom is not the result of words of emotions; instead, as Taniguchi (2005) emphasised, "it refers to one's state of emotion produced with the language use in interaction" (p. 81). We believe that cognitive and affective interaction enables teachers to make informed decisions regarding their teaching practice and the materials they develop and implement.

\section{Materials Development}

Language pedagogy and applied linguistics have recently recognised that MD is a field of study focused on the effect of materials on the teaching-learning process of a foreign language. Researchers such as Bolitho (2003); Maley (2003); McDonough and Shaw (2003); Neville (1991); Núñez, Téllez, and Castellanos (2013); Pulverness (2003); Sercu et al. (2005); Timmis (2002); and Tomlinson (2008) stated that MD entails several issues: inspiration, theoretical foundations, methods and principles supported by effectiveness, suitability, and applicability to current socio-cultural aspects. MD, "as a field of study, demands an informed methodology that allows validating the efficiency, appropriateness and relevance of materials within the context of learning a language" (Núñez et al., 2013, p. 10).

Reflection, awareness of and MD rationale, affect, motivation, teachers' beliefs, creativity, and commitment are the components that interplay in MD. The outcome of this process comprises materials like a book, a module, a didactic unit, a workshop, a worksheet, a lesson, or a learning task. This typology responds to local needs of teaching settings. 
Núñez et al. (2013) affirm that "materials ... are socio-cultural resources that facilitate not only linguistic interaction but also cultural exchanges between the various human groups. Moreover, they are forms of social mediation that allow flow of knowledge" (p. 10). We also agree with Xiaotang's (2004) stance that "materials are not just tools; they represent the aims, values, and methods in teaching a foreign language. Materials are the most powerful device in spreading new methodological ideas and in shaping language teaching and learning practice" (p 1). Thus, developing materials gives teachers the possibility to reflect, innovate, create better teaching and learning settings, and grow as individuals and professionals (Núñez \& Téllez, 2009; Núñez, Téllez, Castellanos, \& Ramos, 2009).

At the MEED, teachers should develop contextualised materials that respond to their students' needs. Materials that address learners' genuine interests, knowledge, experience and understanding of language use create effective learning environments (Cárdenas, 2008; Núñez et al., 2009; Núñez, Pineda, \& Téllez, 2004; Tomlinson, 2003). In this respect, Kessler and Plakans (2001) mention that "[teachers] are the most immediate experts on the needs of ESOL learners, the cognitive abilities of different age groups and the learning process of their specific learners" (p. 15).

\section{Teacher Professional and Personal Development}

Several scholars considered teacher development as an evolving learning process (Cárdenas, González, \& Álvarez, 2010; Diaz-Maggioli (as cited in González, 2007); Freeman, 1989; James, 2001; Richards \& Farrell, 2005). Likewise, Richards and Farrell (2005) deemed teacher professional development as long-term personal growth that aids teachers' defining and making sense of their teaching practice and of themselves as individuals. Moreover, self-development and self-direction are vital for teacher development (Nunan \& Lamb, 1996). As Hiemstra and Brockett (1991) confirmed, they are "characteristics of an individual that predispose one toward taking primary responsibility for personal learning and endeavours" (p. 29). Furthermore, Diaz-Maggioli (as cited in González, 2005) asserted that teacher development is "an ongoing learning process in which teachers engage voluntarily to learn how best to adjust their teaching to the learning needs of their students" (p. 310). Finally, Tomlinson (2003) described teacher development as "a multi-dimensional awareness . . . and the ability to apply this awareness to their actual contexts of teaching" (para. 7).

At the national level, the Ministry of Education (MEN) and the Secretaries of Education (SED) in Colombia established three interrelated pillars for teacher development: Updating, innovating, and researching (Cárdenas et al., 2010), which teacher education programmes ought to address for teacher personal and professional development. Consequently, teacher development entails a long-lasting personal and professional process favouring constant 
self-reflection to enhance EFL teaching and learning potentialities that benefit students' learning endeavours through contextualised materials. In our study, teachers who are enrolled in the MEED are informed along a two-year period to do research and become agents of change by developing and implementing contextualised materials within their contexts for the pedagogical interventions of their research studies.

\section{Research Design}

We adopted a qualitative, interpretative, and descriptive approach, which on the one hand, according to Sandin (2003), is "a systematic activity guided to the comprehension of educational phenomenon and the transformation of the socio-educational sceneries" (p. 123). On the other hand, for Burns (2010) it is suitable to identify problematic situations in a particular context to improve the unsolved concern. This approach also recognises the outcomes given in a natural setting by using methods that imply close interaction with the participants (Snape \& Spencer, 2003). In our study, qualitative findings were complemented by quantitative data gathered through a survey administered to teachers.

\section{Type of Study}

This action research study is an organized reflective process with the purpose of transforming and alleviating a detected concern in a given context (Mills as cited in Mertler, 2009; Stringer as cited in Mertler, 2009; Wallace as cited in Donato, 2003) that also generates changes that improve teaching performance and reflective practices (Burns, 2010). Regarding our research question on how teachers' reflection on the methodology of the MD seminar shapes their personal and professional growth, we followed Kemmis and McTaggart's (1988) cycles of action research, namely, planning the seminar, acting or implementing the reflective activities, observing, and reflecting to make further adjustments.

\section{Context and Participants}

We conducted this study in the MEED at a private university in Bogotá (Colombia), which has a libertarian philosophy and fosters democracy, autonomy, and honesty. Our sample was composed of 31 teachers - 20 women and 11 men enrolled at the MEED-who signed a consent letter. Thirteen teachers were aged from 20 to 30 years, 14 from 30 to 40 , three from 40 to 50 , and one was older than 50 . Out of the 31 teachers, 20 work for public schools and 11 for private institutions; $65 \%$ hold a BA, $16 \%$ have a specialisation degree, and $19 \%$ have been awarded an MA in Education. We sent the survey to all participants from the four groups (60 teachers) who attended the MD seminar. From these 60 teachers, 31 responded to the survey and their answers were analysed. They were chosen based on their willingness, availability, 
and disposition to participate in the study and answer the survey (convenience sampling technique: Steven, 1996; Teddlie \& Yu, 2007).

\section{Data Gathering Instruments}

Survey. A survey is "a systematic method for gathering information from (a sample of) entities for the purpose of constructing quantitative descriptors of the attributes of the larger population of which the entities are members" (Groves et al., 2004, p. 4). As surveys are useful to analyse opinions and perceptions of participants regarding research interests, we administered a structured one (see Appendix) that included demographic, background, and experience questions (Patton as cited in Brown, 2001). The teachers answered it after completing the MD seminar for us to see how their reflection on the methodology of the seminar shapes their personal and professional growth.

Teachers' written reflections. Teachers pondered the content, activities, materials, methodology, and the learning atmosphere of the MD seminar in a written reflection. As Maughan and Webb (2001) sustained, reflecting includes (a) recapturing the experience of an event (our MD seminar); (b) examining the event from several angles (content, activities, materials, methodology, and the learning atmosphere of the MD seminar), and (c) recognising the worth of the event (for teachers' personal and professional growth).

\section{Instructional Design}

Our intervention consisted of several reflective activities on the methodology of the MD seminar to see its impact on teachers' personal and professional growth. They included teachers' perceptions of MD in connection to their teaching; selection of the SLA principles relevant to the development of contextualised materials; statement of the pedagogical criteria for materials selection and evaluation in local contexts; application of the learning principles under the multidimensional approach to plan a lesson; and a final written reflection on the content, materials, activities, methodology, and the learning atmosphere of the MD seminar. These took place during four semesters and were adjusted continuously in an attempt to answer our research concern. Its main objective was to awaken teachers' attitudes and skills to approach MD from a more social, political, and professional perspective when addressing specific problems regarding the contextualisation of materials for the pedagogical intervention of their research studies.

\section{Data Analysis}

We used the grounded approach to analyse the data in which "the codes emerge from the data via a process of reading and thinking about the text material" (Lichtman, 2006, p. 164). 
To identify commonalities and differences and establish relationships among them, we employed the colour-coding technique. Glaser (as cited in Walker \& Myrick, 2006) described the code as "the essential relationship between data and theory" and coding as a process that "gets the analyst off the empirical level by fracturing the data, then conceptually grouping it into codes that then become the theory which explains what is happening in the data" (p. 55). The triangulation process involved the methodological (several sources) and theoretical perspectives (different perspectives) as defined by Denzin and Lincoln (1994).

\section{Results}

\section{Raising Teachers' Awareness of Their Personal and Professional Growth}

This category entails two features: Enhancing teachers' MD knowledge, pedagogical practices, and research projects and Fostering self-confidence, creativity, and self-esteem. For Richards and Farrel (2005), developing professionally implies long-term personal growth that helps teachers define and re-define their pedagogical practice and themselves as individuals. In the Colombian context, the MEN and SED determined that teacher education programmes should address updating, innovating, and researching to reach teachers' personal and professional development (Cárdenas et al., 2010). Tomlinson (2003) highlights that "helping teachers to develop effective materials for themselves can help them to become more positive and confident and to become more effective teachers too" (para. 1).

Enhancing teachers' MD knowledge, pedagogical practices, and research projects. This subcategory refers to teachers' acknowledgment of the role of reflection in increasing their knowledge about the MD field, changing their pedagogical practices, and refining their research projects. Researchers like McGrath (2001); Samuda (as cited in Harwood, 2010); and Tomlinson (2003) declared that MD should be incorporated into teachers' education programmes. By giving participating teachers the opportunity to be informed about $\mathrm{MD}$ and develop contextualised materials for their pedagogical interventions, they expanded their knowledge of MD and grew as individuals and professionals; as stated by Tomlinson (2003): "Providing teachers . . w with the opportunity to develop expertise for themselves as materials developers can quite definitely help them to develop and grow" (para. 9). They also defined and made sense of their pedagogical practices (Richards \& Farrel, 2005) and adapted them to students' needs (Diaz-Maggioli as cited in González, 2007); assumed the responsibility and autonomy for their personal learning (Hiemstra \& Brockett, 1991); and refined their research studies, as illustrated in the excerpts below.

Materials development has been an excellent experience for me to grow in my professional field because the class gives the theoretical foundations of $\mathrm{MD}$, tools to improve, feel confident and 
innovate in my teaching practice by creating materials that take into account students' interests, and complements the pedagogical intervention of my research project. [sic] (Reflection)

The seminar "Materials Development" was a learning space in which motivation and constant reflection influence the teaching practice and in the research process. It is the starting point to develop materials because the seminar gave us self-confidence and motivation at the moment of being creative during the pedagogical intervention of my research project. [sic] (Survey)

The following percentages refer to teachers' perceptions regarding aspects of their professional and personal growth that were influenced by the MD seminar: It gave sense to their teaching practice (32\%), helped re-signify their role as EFL teachers (55\%), aided them to assume responsibility and autonomy for their personal learning $(32 \%)$, and made them adapt their teaching practice to their students' needs $(55 \%)$.

Fifty-eight percent of the teachers affirmed that the seminar caused them to reflect on the impact of materials development in their personal and professional growth and $87 \%$ of the teachers indicated that the MD seminar influenced their knowledge, the innovation in their local context (teaching practice) and the development of their research projects.

Moreover, teachers remarked on the importance of administering a survey to analyse their students' needs in their contexts prior to developing contextualised materials. Regarding students' needs, Diaz-Maggioli (as cited in González, 2007) and Tomlinson (2003), ascertained that teacher development entails refining their insights and skills in learning how to respond to students' needs in particular teaching settings. In this regard, Núñez and Téllez (2008) remarked that "any decision made in the classroom should be informed by a serious needs analysis because it may help teachers be aware of what is actually happening in the classroom" (p. 68). Addressing students' needs in contextualised materials raised teachers' awareness of their personal and professional growth, as can be seen in the following excerpt:

In this seminar I learned to take into account the students' needs and interests at the moment of designing or creating new materials to implement in my pedagogical intervention. Also, I have realized that we teachers as creators of materials can make our classes more attractive and effective. (Reflection)

Getting to know who my students are and their context gives me a closer look at their real selves, their likes, their preferences, their learning styles, their needs; and when I become acquainted with this information, I get to approach my job in a more humane and meaningful way. [sic] (Survey)

Fostering self-confidence, creativity, and self-esteem. The factor that showed teachers' awareness of their personal and professional growth during the MD seminar included empowering themselves in MD. In this sense, Tomlinson (2003) asserted that "teacher development... can lead to the development of teachers with confidence, creativity, 
flexibility and self-esteem (para. 9). Indeed, teachers not only discovered their potentialities to create, adapt, or evaluate materials, but also the resulting effect in terms of self-assurance and self-esteem gained in the MD learning experience. These variables are revealed as aspects involved in MD.

Now, after attending the seminar, I am convinced of my capabilities to develop innovative and attractive materials for my students. I know that designing materials is a valued field that can give me professional opportunities. [sic] (Reflection)

Developing materials requires, besides theory, great creativity on the part of the teacher. It creates appropriate learning settings, enhances students' participation, and promotes teachers' assurance as facilitator and text developer. [sic] (Reflection)

Up to a personal level, I became self-confident with the certainty of doing things well, bearing in mind the students as the main actors of learning. (Survey)

The seminar methodology fosters reflection upon the improvement of materials and motivates creativity. (Survey)

Teachers' reflections emphasised their role of being innovative and self-confident to influence their educational context, and also a strong sense of worth regarding MD. We agree with Tomlinson's (2003) view, to wit:

A materials development as teacher development course can not only help teachers to develop useful expertise as materials developers. It can also help teachers to articulate and develop their own theories of language learning and teaching, to develop skills which can enable them to apply these theories to practice and to develop personal attributes which can help them to become more confident and positive people and more effective teachers too. (p. 32)

The excerpts below show teachers' role as innovative and self-confident agents who influence their educational context regarding the aforementioned aspects.

I have learned that materials development is an innovative activity that allows teachers to explore different alternatives to develop creativity. It also offers opportunities for professional growth and opens doors in the labor market. [sic] (Reflection)

Forty-two percent of the teachers said that the seminar allowed them to increase their self-confidence, creativity, and self-esteem as teachers and as persons.

I also learned to do it [develop materials] with passion to improve not only communicative skills, but also self-esteem. [sic] (Survey)

\section{Creating a Reflective Learning Environment}

This category and its two subcategories-Engaging teachers in relevant activities and Motivating reflection on teachers' pedagogical and research practice-are associated with aspects such as challenging teachers in reflective activities and generating a sense of engagement. Regarding 
these aspects, Tomlinson (2003) mentioned that MD "encourage[s] reflection and self-evaluation so that the teachers can learn from themselves and can develop the habit of positive but critical reflection on their attempts to help their learners" "The Principles of Materials Development," para. 7). Teachers learnt that reflection should be part of daily practice in the materials they develop to motivate students towards learning the English language, as illustrated in the two subcategories.

Engaging teachers in relevant activities. This subcategory implies inviting teachers to participate in activities to interpret, deduce, and contextualise components of the MD process such as reflection, awareness of an MD rationale, affect, motivation, teachers' beliefs, creativity and commitment. The activities proposed in the seminar aim at sharpening teachers' insights on an MD rationale, a vital issue for making informed decisions when developing materials. The knowledge of the MD rationale involves an informed theoretical framework for MD, SLA principles, MD tenets derived for the former, a theory of the nature of language and language learning, and a methodological teaching and learning approach underlying teacher-generated materials.

In view of the teachers' voices, the professor's knowledge of the MD domain, her personal way of placing affect at the centre of her approach plus her devotion and personality traits all played a fundamental role to create an engaging learning atmosphere. In this regard, Tomlinson (2000) remarked on the importance of engaging affect when "creating an environment in which learning is a stimulating, enjoyable and successful experience" (para. 11), as evidenced in the following excerpts:

[The professor] carefully selects the materials to provide theoretical support to the topic under study; she engages us in pertinent activities and brings inspirational messages ... to sweeten even the heaviest theoretician and involves us in reflective practices to improve the pedagogical intervention of our research project. All the materials she has provided have proven to be highly illustrative and up to the level we need in the program. [sic] (Reflection)

The class activities were appropriate to motivate reflection on the materials developed for the pedagogical intervention — adjusted to our contexts—and the improvement of our pedagogical practice. [sic] (Survey)

The engagement caused by constructive activities might also be the result of the professor's role model, which permeates teachers' learning. In this regard, Bandura (as cited in Schuman \& Relihan, 1990) noticed that "individuals will imitate the behaviour of a person they respect and with whom they have a rapport ... the use of modeling as a teaching tool has been shown to be effective" (p. 106).

Motivating reflection on teachers' pedagogical and research practice. This subcategory deals with the role of reflection on teachers' pedagogical and research practices as key aspects toward which to draw attention in the seminar. Jabbar (2015) 
affirmed that "within the literature of professionalism, there are certain strategies and tools that an English teacher should adopt to develop his competence and performance. Reflective practice, which is an exploratory process, is one of these strategies" (p. 1). In Harmer's view "it is important for [the] teacher to keep a record of what works and what doesn't (for the class and for individual students. Reflective teachers do this anyway, and it helps them to design what to do next") (as cited in Ramos \& Aguirre, 2014, p. 141). The transcriptions below illustrate the importance of teachers' reflections in their research process.

The seminar "Materials development" and the learning environment created in it involve motivation and constant reflection on the teaching practice and on the research process. [sic] (Reflection)

Posing a successful research study based on learning process mainly depends on the serious systematized process of reflection about learning processes performed by teacher-researchers, in response to students' needs and interests. [sic] (Survey)

\section{Awakening Teachers' Positive Affective State}

This category embraces two subcategories: Enriching cognitive and affective interaction and Humanising teaching practices, two basic components in teaching and learning endeavours. In this respect, we follow Lei's (2007) view about the "humanistic approach . . . characterized by learner-centeredness in that a student is first of all regarded as a person-a whole being, with his individual characters both in cognition and in affect" (p. 60). Lei also stated that teachers may foster students' interaction, which facilitates students' awareness of their learning process, attention and motivation and, thus, builds "positive affective state" in the classroom.

Enriching cognitive and affective interaction. The seminar provided constant interaction opportunities aimed at reflection and class discussions. Taniguchi (2005) highlighted that affect is "something produced not by using expressions of emotions. Rather, it refers to one's state of emotion produced with the language use in interaction" (p. 81). Giving teachers the chance to share experiences and knowledge, have their voices heard, and build knowledge together within a comfortably engaging environment allows for cognitive and affective interaction. This is a more conducive setting for individuals to be more involved in learning and more confident to apply what they theorise if they are exposed to reflection, discussion, and informed action.

Furthermore, affect, motivation, and confidence augment knowledge apprehension. Correspondingly, Krashen (as cited in Lei, 2007) developed the theory of "the Affective Filter Hypothesis," which refers to the role of the filter as regards the amount of input students can 
deal with and the amount they can actually apprehend. The affective quality relies on motivation, self-assurance, and levels of anxiety, which in Lei's (2007) view:

Highly motivated and self-confident learners, with low anxiety have low filters and so obtain and let in plenty of input. Learners with low motivation, little self-confidence, and high anxiety have high filters and so receive little input and allow even less in. (p. 61)

From our view, the "positive affective state", generated in the MD seminar sparked teachers' motivation to become better individuals and professionals. The next instances corroborate the preceding variable.

Being part of her classes has made me reformulate the conception I had of that very word: class. Yes, it is a place to learn, but is can be warm, welcoming, soothing; it can be fun. And so it is. Not only do we get to listen to our professor, but our voice is also heard; therefore, learning comes and goes from every participant, while we all share our experiences and knowledge. (Reflection)

In what concerns to my personal and professional growth, I realised that students need to be considered as important human beings who need love and understanding. Affect fosters a positive atmosphere to awake real interest in learning processes. [sic] (Survey)

Humanising teaching practices. Lei (2007) asserts that humanising our practices may lead to better learning undertakings. The humanising approach pursued by the MD professor is crucial to perform the role of "a facilitator" rather than that of "an instructor" and advocates for equal treat of learners. Tomlinson's (2000) insights about potentiating students to learn consciously using the multidimensional approach have shed light on the methodology of the seminar. Based on the assumptions of these two approaches, we have become fully aware that the humanising endeavour of the seminar enhances teachers' learning; augments chances for meaningful experiences in their teaching contexts; and creates affection, which may eventually be replicated in their particular settings through the materials developed for the pedagogical intervention of their research projects. The excerpts beneath illustrate the aspects discussed above.

The teacher's approach was mainly based on touching our heart and then, pass to our mind making of the learning process a meaningful experience with long-lasting effects because we will probably never forget what we have learnt along this course. [sic] (Reflection)

Humanising teaching practise fosters teachers' awareness of individuals' interests and needs to consider when developing and adapting materials; also motivate EFL teachers to start research to transform education. [sic] (Survey)

\section{Conclusions}

Reflecting on teachers' personal and professional growth through a materials development seminar raises teachers' awareness of personal and professional growth by enhancing their discipline knowledge, pedagogical practices, and research projects as well as fostering 
self-confidence, creativity, and self-esteem. Indeed, Richards and Farrell (2005) argued the role of reflection in characterising teaching practices and individuals. Furthermore, Cárdenas et al., (2010) emphasised the need to promote updating, research, and innovation in teacher education programmes to reach teacher personal and professional development. The purpose of the MD seminar can be described using Núñez and Téllez's (2009) words: “materials development contributes directly to teachers' professional growth insofar as it betters their knowledge, skills and creativity, raises their consciousness as regards teaching and learning procedures, and allows them to act as agents of permanent change" (p. 184).

Reflection also serves the purpose of creating a reflective learning environment that engages teachers in appropriate and relevant activities, and motivates them to ponder their pedagogical and research practices. The seminar activities helped teachers realise the importance of reflecting to better their classes and materials and facilitate students' learning of the English language. Conveniently, Núñez and Téllez (2009) elaborated on the relationship among materials and learning pedagogical practices: "Teacher-developed materials boost not only effective learning settings and outcomes, but also teachers' pedagogical practice/performance" (p. 184). Teachers' reflection strengthened their pedagogical interventions and assisted them in attaining the purposes of their research studies.

Reflection contributes to awaken teachers' positive affect by providing cognitive and affective interaction opportunities, and by humanising teaching practices as essential pillars behind teaching and learning purposes. This boosted teachers' awareness to address their students' wants when developing materials and to start doing research aimed at transforming their educational setting. In this respect, Lei (2007) and Tomlinson (2001) highlight the need to humanise pedagogical practices and materials, respectively, which implies teachers fostering classroom interaction through the development and implementation of meaningful materials to favour students' cognitive and emotional engagement as they relate their content and activities to their own lives and immediate context.

Reflective practice given in the seminar, the multidimensional approach implemented, the professor's knowledge and expertise in sharpening teachers' insights on a MD rationale, and the rapport and inspiring learning atmosphere promoted teachers' awareness of personal and professional development. Consequently, several teachers were enabled to perform as novice text developers in a recognised publishing house in Colombia.

\section{References}

Barlett, L. (1990). Teacher development through reflective teaching. In J. C. Richards \& D. Nunan (Eds.), Second language teacher education (pp. 202-214). Cambridge, UK: Cambridge University Press. 
Bolitho, R. (2003). Materials for language awareness. In B. Tomlinson (Ed.), Developing materials for language teaching (pp. 422-425). London, UK: Continuum.

Brown, J. D. (2001). Using surveys in language programs. Cambridge, UK: Cambridge University Press.

Burns, A. (2010). Doing action research in English language teaching: A guide forpractitioners. New York, NY: Routledge.

Cárdenas, M. L. (2008, July). From the President: Our 43rd ASOCOPI Annual Conference is Coming! ASOCOPI Newsletter. Retrieved from http://www.asocopi.org/files/ newsletterJuly2008Final.pdf.

Cárdenas, M. L., González, A., \& Álvarez, J. A. (2010). El desarrollo profesional de los docentes de inglés en ejercicio: algunas consideraciones conceptuales para Colombia [In service English teachers' professional development: Some conceptual considerations for Colombia]. Folios, 31, 49-68.

Denzin, N. K., \& Lincoln, Y. S. (1994). Introduction: The discipline and practice of qualitative research. In N. K. Denzin \& Y. S. Lincoln (Eds.), Handbook of qualitative research (pp. 1-36). London, UK: Sage Publications.

Donato, R. (2003, December). Action research. ERIC Digest. Retrieved from http:// www.cal.org/resources/digest/0308donato.html.

Freeman, D. (1989). Teacher training, development, and decision making: A model of teaching and related strategies for language teacher education. TESOL Quarterly, 23(1), 27-45. http://dx.doi.org/10.2307/3587506.

Giovanelli, M. (2003). Relationship between reflective disposition toward teaching and effective teaching. The Journal of Educational Research, 96(5), 293-309. http://dx.doi.org/10.1080/ 00220670309597642.

González, A. (2007). Professional development of EFL teachers in Colombia: Between colonial and local practices. Íkala, Revista de Lenguaje y Cultura, 12(18), 309-332.

Groves, R. M., Fowler, F. J., Couper, M. P., Lepkowski, J. M., Singer, E., \& Tourangeau, R. (2004). Survey methodology. Hoboken, NJ: John Wiley \& Sons.

Harwood, N. (2010). Language teaching materials: Theory and practice. Cambridge, UK: Cambridge University Press.

Hiemstra, R., \& Brockett, R. (1991). From behaviorism to humanism: Incorporating self-direction in learning concepts into the instructional design process. In H. B. Long (Ed.), New ideas about self-directed learning (pp. 59-80). Norman, OK: Oklahoma Research Center for Continuing Professional and Higher Education.

Jabbar, I. (2015). Professional development in EFL classroom: Motivation and reflection. International Scholarly and Scientific Research \& Innovation, 2(1), 1.

James, P. (2001). Teachers in action: Tasks for in-service language teacher education and development. Cambridge, UK: Cambridge University Press.

Kemmis, S., \& Mc'Taggart, R. (1988). The action research reader. Melbourne, AU: Deakin University Press. 
Kessler, G., \& Plakans, L. (2001). Incorporating ESOL learners' feedback and usability testing in instructor-developed CALL materials. TESOL Journal, 15-20. Retrieved from https:// www.ohio.edu/linguistics/kessler/articles/kesslerPlakans2001.pdf.

Lei, Q. (2007). EFL teachers' factors and students' affect. US-China Education Review, 4(3), 60-67.

Lichtman, M. (2006). Qualitative research in education. A users' guide. Thousand Oaks, CA: Sage Publications, Inc.

Loughran, J. J. (2002). Effective reflective practice: In search of meaning in learning about teaching. Journal of teacher education, 53(1), 33-43. http://dx.doi.org/10.1177/0022487102053001004.

Maley, A. (2003). Creative approaches to writing materials. In B. Tomlinson (Ed.), Developing materials for language teaching (pp. 183-198). London, UK: Continuum.

Mann, S. (2005). The language teacher's development. Language Teaching, 38(3), 103-118. http://dx.doi.org/10.1017/S0261444805002867.

Maughan, C., \& Webb, J. (2001). Small group learning and teaching. Retrieved from thehttp:// 78.158.56.101/archive/law/resources/teaching-and-learning-practices/groups/index.html.

McDonough, J., \& Shaw, C. (2003). Materials and methods in ELT: A teacher's guide (2nd ed.). Malden, MA: Blackwell Publishing.

McGrath, I. (2001). Materials evaluation and design for language teaching. Edinburgh, UK: Edinburgh University Press.

Mertler, C. A. (2009). Action research: Teachers as researchers in the classroom (2nd ed.). Thousand Oaks, CA: Sage Publications.

Neville, G. (1991). Making the most of your textbook. Essex, UK: Longman.

Nunan, D., \& Lamb, C. (1996). The self-directed teacher: Managing the learning process. Cambridge, UK: Cambridge University Press.

Núñez, A., \& Téllez, M. F. (2008). Meeting students' needs. Enletawa Journal, 1, 65-68.

Núñez, A., \& Téllez, M. F. (2009). ELT materials: The key to fostering effective teaching and learning settings. PROFILE Issues in Teachers' Professional Development, 11(2), 171-186.

Núñez, A., Pineda, C., \& Téllez, M. F. (2004). Key aspects for developing your instructional materials. PROFILE Issues in Teachers' Professional Development, 5, 128-139.

Núñez, A., Ramos, B., \& Téllez, M. F. (2006). Reflexión en el contexto educativo: hacia la toma de decisiones en el aula [Reflection in the educational context: Towards decision making in the classroom].@puntesCont@bles, 11,111-115.

Núñez, A., Téllez, M. F., \& Castellanos, J. (2013). Proposal for the research line materials development and didactics (Ascribed to the Research Group: Critical Pedagogy and Didactics for Social Transformation). Universidad Externado de Colombia, Bogotá.

Núñez A., Téllez M. F., Castellanos J., \& Ramos B. (2009). A practical materials development guide for EFL pre-service, novice, and in-service teachers. Bogotá, CO: Departamento de Publicaciones Universidad Externado de Colombia.

Oxford, R. L. (1990). Language learning strategies: What every teacher should know. New York, NY: Newbury House. 
Pollard, A., \& Tann, S. (1993). Reflective teaching in the primary classroom. London, UK: Wellington House.

Pulverness, A. (2003). Materials for cultural awareness. In B. Tomlinson (Ed.), Developing materials for language teaching (pp 426-438). New York, NY: Continuum.

Ramos, B., \& Aguirre, J. (2014). Materials development in the Colombian context: Some considerations about its benefits and challenges. HOW, 21(2) 134-150.

Richards, J. C., \& Farrell, T. S. C. (2005). Professional development for language teachers. Cambridge, UK: Cambridge University Press. http://dx.doi.org/10.1017/CBO9780511667237.

Sandin, M. P. (2003). Investigación cualitativa en educación: fundamentos y tradiciones [Qualitative research in education: Fundamentals and tradition]. Madrid, ES: McGraw-Hill.

Schuman, D. R., \& Relihan, J. (1990). The role of modeling in teacher education programs. Reading Horizons, 31(2) 105-112. Retrieved from http://scholarworks.wmich.edu/cgi/viewcontent. cgi? article $=1604 \&$ context $=$ reading_horizons.

Sercu, L., Bandura, E., Castro, P., Davcheva, L., Laskaridou, C., Lundgren, U., . . Ryan, P. (2005). Foreign language teachers and intercultural competence: An international investigation. Clevedon, UK: Multilingual Matters.

Snape, D., \& Spencer, L. (2003). The foundations of qualitative research. In J. Ritchie \& J. Lewis (Eds.), Qualitative research practice: A guide for social science students and researchers (pp. 1-23). London, UK: Sage Publications.

Stevens, J. P., (1996). Applied multivariate statistics for the social sciences (3rd ed.). Mahwah, NJ: Lawrence Earlbaum Associates.

Taniguchi, Y. (2005). Affect and the EFL classroom: Language contact in addressing. In B. Preisler., A. Fabricius., H. Haberland, S., Kjærbeck., \& K. Risager (Eds.), The consequence of mobility (pp. 80-92). Roskilde, DK: Roskilde University. Retrieved from http:// rudar.ruc.dk/bitstream/1800/8710/1/Taniguchi.pdf.

Teddlie, C., \& Yu, F. (2007). Mixed methods sampling a typology with examples. Journal of Mixed Methods Research, 1(1), 77-100. http://dx.doi.org/10.1177/2345678906292430.

Timmis, I. (2002). Native speaker norms and international English: A classroom view. ELT Journal, 56(3), 240-249. http://dx.doi.org/10.1093/elt/56.3.240.

Tomlinson, B. (2000). A multi-dimensional approach. The Language Teacher. Retrieved from http://jalt-publications.org/old_tlt/articles/2000/07/tomlinson.

Tomlinson, B. (2001). Humanising the Coursebook. Humanising Language Teaching. Pilgrims Home, 3(5), 1. Retrieved from http://www.hltmag.co.uk/sep01/mart1.htm.

Tomlinson, B. (2003). Developing materials to develop yourself. Humanising Language Teaching, 5(4). Retrieved from http://www.hltmag.co.uk/jul03/mart1.htm.

Tomlinson, B. (2008). English language learning materials: A critical review. London, UK: Continuum.

Viafara, J. J. (2005). The design of reflective tasks for the preparation of student teachers. Colombian Applied Linguistics Journal, 7, 53-74.

Wallace, M. J. (1991). Training foreign language teachers: A reflective approach. Cambridge, UK: Cambridge University Press. 
Walker, D., \& Myrick, F. (2006). Grounded theory: An exploration of process and procedure. Qualitative Health Research, 16(4), 547-559. http://dx.doi.org/10.1177/1049732305285972.

Xiaotang, C. (2004). Current trends in syllabus design and materials development. School of Foreign Languages and Literature, Beijing Normal University, Beijing, China.

\section{The Authors}

Astrid Núñez Pardo, a professor in the Master's Programme in Education at Universidad Externado de Colombia, is currently pursuing her $\mathrm{PhD}$ in Education at UPTC (Colombia). She holds an MA in Education, a Specialisation in International Economics, a BA in Hotel and Tourism Business Management from Universidad Externado de Colombia, and a Diploma in Linguistic Studies from the University of Essex (UK).

María Fernanda Téllez Téllez, a professor in the Master's Programme in Education at Universidad Externado de Colombia, is pursuing her $\mathrm{PhD}$ in Education at UPTC (Colombia). She holds an MA in Education from Universidad Externado de Colombia, a BA in Business Administration from Fundación Universitaria San Martín, and a BA in Modern Languages from Universidad de Los Andes (Colombia).

\section{Acknowledgments}

We would like to thank the editor and the reviewers for their valuable suggestions to improve this article. 


\section{Appendix: Survey for Teachers}

\section{The Role of Reflection on the Methodology Implemented in the Materials Development Seminar in your Personal and Professional Growth}

Please, read the questions of the following survey carefully and select the most appropriate choice to answer with honesty. Thank you for your time.

1. Choose your age range

Between 20 and 30

Between 30 and 40

Between 40 and 50

Older than 50

2. Indicate your academic studies

Undergraduate

Specialisation

Master
Title:

Title:

Title:

3. Indicate the context and the academic level you work on

Public

Private
Preschool

Basic primary school

Basic secondary school

High school

Undergraduate

Postgraduate

Others:

4. Select the options that reflect your perceptions on the learning experience in the MD seminar.

a. The seminar persuaded me of the fact that we teachers are the ones called upon to develop in-house materials for teaching English.

b. The seminar raised my awareness, inspired me, and awakened my desire for developing materials. 
c. The seminar explained/broadened my concept and the typology on Materials Development.

d. The seminar instructed and exemplified how to begin the materials design process by using a needs analysis.

e. The seminar provided me with information on language perspective and its learning, and helped me identify the methodology and pedagogical approach behind materials development.

f. The comparison and contrast of various teaching-learning theories caused me to reflect.

g. The seminar allowed me to establish the acquisition principles to learn a foreign language and to derive from them the appropriate principles to develop materials according to my local context.

h. The seminar instructed me on how to carry out a systematic and objective evaluation in order to adapt materials to my local context needs.

i. The seminar raised my awareness on the need to select, adapt, and develop in-house materials to benefit effective learning environments.

j. The seminar persuaded me of the necessity to use suitable, relevant, and adapted materials, considering students' interests, expectations, and needs.

k. The seminar caused me to reflect on the theoretical fundamentals and the practical principles for developing materials as a scientific activity.

1. The seminar clarified the difference among objectives, strategies, and activities when learning a foreign language.

m. The seminar helped me assume a critical perspective on teaching materials as a pedagogical tool (socio-cultural artefact) that plays a part in the teaching-learning processes of English as second language.

n. The seminar provided me with the current tendencies and future research possibilities on the design and use of materials.

o. The seminar caused me to reflect on the impact of materials development in my personal and professional growth.

p. The seminar helped me reflect on the instructional/pedagogical fundamentals to design my research project.

q. Others:

5. Describe your perception as regards the role of reflection on the students' needs analysis in your personal and professional development. 
6. Describe your perception as regards the role of reflection on the methodology implemented in the seminar on "Materials Development" in your personal and professional growth.

7. Indicate which of the following items were influenced by the seminar on Materials Development.

The updating of my knowledge

The innovation of my local context

The development of my research project

All of the above

None

Others. Specify:

8. Indicate which of the following items were influenced by the seminar to consolidate Materials Development.

To give sense to my teaching practice

To re-signify my role as an EFL teacher

To guide my personal objectives in an autonomous way

To assume responsibility and autonomy for my personal learning

To adapt my teaching practice to my students' needs

To apply a multidimensional awareness to my local teaching practice

To reflect on a permanent basis on my personal and moral growth

To reconsider my mission as a teacher

To make the understanding and implementation of language learning theories easier

To strengthen my self-confidence, creativity, and self-esteem as a teacher and as a person

All of the above

None

Others. Specify:

Thank you again for your kind attention and cooperation. 